\title{
Calf Diseases and Mortality in Swedish Dairy Herds
}

\author{
By S.-O. Olsson, S. Viring, U. Emanuelsson and S.-O. Jacobsson
}

Swedish Association for Livestock Breeding and Production, Animal Health Department, Eskilstuna, Swedish Farmers' Meat Marketing Association, Animal Health Service, National Veterinary Institute, Uppsala, and Swedish University of Agricultural Sciences, Veterinary Faculty, Department of Cattle and Sheep, Uppsala, Sweden.

\begin{abstract}
Olsson, S.-O., S. Viring, U. Emanuelson and S.-O. Jacobsson: Calf diseases and mortality in Swedish dairy herds. Acta vet. Scand. 1993, 34, 263-269. - A survey of the mortality and morbidity affecting calves during the first 3 months of life was carried out. Results are reported from 131 herds with altogether 5,050 calvings. These herds kept individual calf cards for all calves born. The incidences of abortions and stillborn calves were $0.6 \%$ and $3.6 \%$, respectively. During the period $0-90$ days the mortality and morbidity were $2.6 \%$ and $11.0 \%$, respectively. The frequencies of enteritis and pneumonia in calves were $7.2 \%$ and $0.8 \%$. Mortality and morbidity were influenced by breed, season, age of the dam and time of first colostrum. The frequencies of abortions, stillborn calves, mortality and morbidity varied considerably between herds. Herd factors influencing mortality and morbidity during different periods of time were: herd size, yield, zero-grazing, whether the calf was allowed to feed by suckling, the design of the calf pens, and previous incidence of infectious enteritis in the herd. On average, both mortality and morbidity in calves were low, though in certain herds, temporarily high frequencies were registered.
\end{abstract}

morbidity; enteritis; pneumonia; predisposing factors.

\section{Introduction}

The mortality and morbidity of calves vary considerably between different countries and also between herds in the same region. For example, Simensen (1982) reported a mortality rate of $1 \%$ in Norway, in contrast to Germany, where Hartman et al. (1974) recorded $27 \%$. In a survey covering England, Wales and Scotland, a mortality rate for home-bred calves was estimated to $5 \%$ up to 6 months of age and it was argued that a mortality rate at that level can be tolerated economically (Roy 1990). In addition, abortions accounted for $2.1 \%$ and stillbirths for 3.3 to $5.9 \%$ of parturitions (Leeck et al. 1968, Bakheit \& Greene 1981 , Roy 1990). Of the $5 \%$ deaths, $64-75 \%$ occurred during the first month of life. The most frequent diseases observed by Leeck et al. (1968) were scouring ( $8.9 \%)$ and coughing (3.8\%) among the calves. In an earlier Swedish study (Lindhé 1967) a rate of $2.93-3.86 \%$ stillborn calves was reported in different Swedish breeds. Congenital malformations were $0.073 \%$ and $0.055 \%$ for the Swedish Red and White breed and for Swedish Friesian, respectively.

In Sweden there is very little data on levels of calf mortality and morbidity. It is known, however, that about one-third of all heifers born in milk-recorded herds are "lost" between birth and first calving (SHS 1987/88). Most of these "lost" heifers are probably used for beef production, but there is no reliable information as regards mortality, morbidity and the numbers culled due to injury or disease. 
The aim of the present investigation was to ascertain the mortality and morbidity among calves during the first 3 months of life in Swedish dairy herds and to identify possible relationships between mortality, morbidity, environment, and management.

\section{Material and methods}

Initially the study comprised 6,164 calves in 200 herds belonging to 10 local livestock associations covering all regions of Sweden. Of the cows, $56.8 \%$ were of the Swedish Red and White breed and $36.8 \%$ were Swedish Friesian. The remainder were of minor breeds and crosses. The herds were purposely sampled so as to meet specific criteria: herds had to be enrolled in both the milk-recording and the artificial insemination programmes, to have between 20 and 50 dairy cows, and to be judged by the local extension personnel to be highly likely to keep complete and thorough records, in order to be eligible for inclusion. The local extension personnel were explicitly instructed that no selection was to be allowed on the basis of presence, or absence, of particular disease problems.

On an individual calf card, the farmers were asked to record all diseases, treatments and reasons for culling for all calves born during the period September 1st, 1987, to September 30th, 1988. These recordings continued until December 31st, 1988, and the period of observation was therefore at least 3 months for all calves. Staff from the local livestock associations or practising veterinarians visiting farms made monthly checks of the recordings.

The symptoms/diseases registered were enteritis, cough/pneumonia or combinations of these, spasms/paralysis, umbilical hernia, umbilical abscess, hoof diseases, accidents, cheek abscess, ringworm and congenital defects. Other diseases could also be reported. However, many of the incidences were low (less than $1 \%$ ), and therefore only enteritis, cough/pneumonia and total figures are included in this paper.

The calf cards were compared with the official calving records of the milk-recording programme. Data were excluded from the material if the reports amounted to less than $75 \%$ of the officially recorded calvings within herd. For that reason 1,114 calf cards from 69 herds were excluded from the material.

Once during the trial period the farmers were interviewed by extension personnel regarding the environment, management and feeding of calves. A special questionnaire was used, comprising 28 different parameters.

Incidences, overall and within herd, were calculated for mortality, enteritis, cough/pneumonia and total morbidity for 4 periods: within $24 \mathrm{~h}$ of birth, 1 to 7 days after birth, 8 to 30 days after birth, and 31 to 90 days after birth. Some calves $(n=885)$ were also followed from 91 days up to an age of at least 12 months but not more than 15 months. Incidences for each period were calculated as number of calves affected, divided by number of calves at risk. Calves at risk were estimated as number of calves at the beginning of the period, that had not had the particular diagnosis previously, minus half of the number of calves that left the herd during the period.

A Cox's proportional hazards model (e.g. Lee 1980), as applied in PROC PHGLM of SAS (SAS Institute Inc. 1983), was used to study the risk of death and of contracting enteritis, cough/pneumonia, or any disease in individual calves. The analyses were performed with herd as a stratifying variable.

Potential explanatory variables were: breed (Swedish Red and White vs. other) and parity (first vs. later) of the dam, season of birth (May - September vs. other), sex of calf, and age of the calf when first colostrum was fed (in hours). The final model was found by back- 
Table 1. Mortality and morbidity in 4,839 liveborn calves.

\begin{tabular}{rcccc}
\hline $\begin{array}{l}\text { Age } \\
\text { (days) }\end{array}$ & $\begin{array}{c}\text { Mortality } \\
(\%)\end{array}$ & $\begin{array}{c}\text { Enteritis } \\
(\%)\end{array}$ & $\begin{array}{c}\text { Pneumonia } \\
(\%)\end{array}$ & $\begin{array}{c}\text { Morbidity } \\
(\%)\end{array}$ \\
\hline $0^{\mathrm{a}}$ & 0.2 & $<0.1$ & 0.0 & 0.3 \\
$1-7$ & 0.7 & 1.0 & 0.1 & 1.8 \\
$8-30$ & 0.6 & 3.5 & 0.2 & 5.0 \\
$31-90$ & 0.8 & 2.0 & 0.5 & 2.9 \\
\hline
\end{tabular}

${ }^{\text {a }}$ First day of life.

ward stepwise elimination of non-significant ( $p>0.05$ ) factors and the results are interpreted as hazard-rate ratios (HRR; analogous to the relative risk).

The effects of herd factors, correlated to environment and management, on incidences of mortality, enteritis, cough/pneumonia, and total morbidity were studied with logistic regression analysis as applied in PROC CATMOD of SAS (SAS Institute Inc. 1985). Analyses were conducted separately for each outcome and each time period. Furthermore, only univariate analyses were performed due to many missing values, collinearity among some factors and low dispersion for some factors.

\section{Results}

Data were studied from 131 herds with a total of 5,050 calvings.

\section{Individual results}

The incidence of abortions was $0.6 \%$ and of stillborn calves, $3.6 \%$. No significant differences between parity, breed and season could be found.

Mortality and morbidity rates at different ages are shown in Table 1.

During the period 0-90 days the overall mortality and morbidity rates were $2.6 \%$ and $11.0 \%$, respectively. Enteritis and pneumonia were recorded in $7.2 \%$ and $0.8 \%$ of the calves, respectively.

Calves born alive by primiparous cows had a higher mortality than calves born by older cows. Enteritis was more common in Swedish Red and White calves than in other breeds. Enteritis was less frequent in calves born in the summer (May - September) than during other seasons. Morbidity was more prevalent in Swedish Red and White calves than in other breeds. The age of the calf when first colostrum was fed affected the incidence of enteritis and morbidity. Each hour of delay within the range 1-12 hours increased the risk by $10 \%$ that the calf would be taken ill. These results are summarized in Table 2 .

\section{Herd results}

Inter-herd variation as regards abortions, stillborn calves, mortality and morbidity is shown in Table 3. The incidence of cough/pneumonia was very low. Most of the farmers reported no cases in their herds.

Increasing herd size and zero-grazing was found increase calf mortality within $24 \mathrm{~h}$ of

Table 2. Summary of final Cox's proportional hazards model for mortality and morbidity.

\begin{tabular}{lll}
\hline $\begin{array}{l}\text { Outcome } \\
\text { variable }\end{array}$ & $\begin{array}{l}\text { Explanatory } \\
\text { variable }\end{array}$ & HRR $^{\mathrm{a}}$ \\
\hline Mortality & Primiparous cows & 1.6 \\
& Older cows & 1.0 \\
Enteritis & Swedish Red and White breed & 2.3 \\
& Other breeds & 1.0 \\
& Season (May - September) & 0.8 \\
& " (October - April) & 1.0 \\
& Age, colostrum & 1.1 \\
Morbidity & Swedish Red and White breed & 1.4 \\
& Other breeds & 1.0 \\
& Age, colostrum & 1.1 \\
\hline
\end{tabular}

${ }^{a}$ Hazard-rate ratio. 
Table 3. Abortions, stillborn calves, mortality, enteritis, pneumonia and morbidity. Medians, 75 th and 90 th percentiles, respectively, and maximum values for within-herd incidences.

\begin{tabular}{|c|c|c|c|c|c|}
\hline Variable & $\begin{array}{c}\text { Time period } \\
\text { (days) }\end{array}$ & Median & $75 \%$ & $90 \%{ }^{N}$ & $\begin{array}{l}\text { Maximum } \\
\text { value }\end{array}$ \\
\hline Abortion & - & 0 & 0 & 2.4 & 7.4 \\
\hline $\begin{array}{l}\text { Stillborn } \\
\text { calves }\end{array}$ & - & 2.9 & 5.9 & 9.0 & 14.7 \\
\hline Mortality & $\begin{array}{r}0^{\mathrm{a}} \\
1-7 \\
8-30 \\
31-90\end{array}$ & $\begin{array}{l}0 \\
0 \\
0 \\
0\end{array}$ & $\begin{array}{l}0 \\
0 \\
0\end{array}$ & $\begin{array}{l}0 \\
3.1 \\
2.7 \\
3.9\end{array}$ & $\begin{array}{l}4.3 \\
6.2 \\
9.5 \\
8.7\end{array}$ \\
\hline Enteritis & $\begin{array}{r}0 \\
1-7 \\
8-30 \\
31-90\end{array}$ & $\begin{array}{l}0 \\
0 \\
0 \\
0\end{array}$ & $\begin{array}{l}0 \\
0 \\
4.4 \\
0\end{array}$ & $\begin{array}{r}0 \\
3.8 \\
10.9 \\
6.6\end{array}$ & $\begin{array}{r}3.2 \\
16.0 \\
48.8 \\
19.6\end{array}$ \\
\hline Pneumonia & 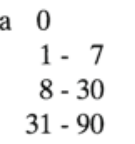 & $\begin{array}{l}0 \\
0 \\
0 \\
0\end{array}$ & $\begin{array}{l}0 \\
0 \\
0 \\
0\end{array}$ & $\begin{array}{l}0 \\
0 \\
0 \\
2.0\end{array}$ & $\begin{array}{l}0 \\
4.2 \\
7.8 \\
7.8\end{array}$ \\
\hline Morbidity & $\begin{array}{r}0 \\
1-7 \\
8-30 \\
31-90\end{array}$ & $\begin{array}{l}0 \\
0 \\
1.7 \\
0\end{array}$ & $\begin{array}{l}0 \\
2.4 \\
6.1 \\
3.8\end{array}$ & $\begin{array}{r}0.6 \\
5.0 \\
15.8 \\
11.0\end{array}$ & $\begin{array}{r}9.5 \\
24.0 \\
48.8 \\
17.5\end{array}$ \\
\hline
\end{tabular}

${ }^{\text {a }}$ First day of life.

birth $(\mathrm{OR}=1.04$ and 10.79 , respectively $)$ as well as between 1 and 7 days of age (Table 4). In herds where the calves were allowed to suckle mortality within $24 \mathrm{~h}$ and the incidence of enteritis were also higher. Other factors that were detrimental to calf health were slatted floors in the calf pens, previous cases of enteritis in the herd, cows grazing together with cows from other herds, and increasing yield level. On the other hand, individual pens and cows tethered at calving were 2 factors which improved the calves' health, as evident in Table 4.
In older calves, 31-90 days of age, the morbidity increased if the herd had previously had cases of contagious enteritis $(\mathrm{OR}=2.45)$. At this age, morbidity also increased with increasing herd size $(\mathrm{OR}=1.01)$.

In 885 heifer calves in the 131 herds, mortality and morbidity were studied from 91 days of age up to an age of at least 12 months and not more than 15 months. The observation period of 15 months for these calves fell within the period of the investigation. Mortality and morbidity were $1.0 \%$ and $4.6 \%$, respectively. Enteritis was recorded in $2.4 \%$ and pneumonia in $1.6 \%$ of the calves.

\section{Discussion}

In field surveys, there is a risk that some cases may be overlooked. In order to reduce errors in the results of the present investigation, $34.5 \%$ of the herds and $18.1 \%$ of the calves were excluded from the material because the difference between the cards in question and the officially recorded calvings of the herds was too high. Ekesbo (1966) considered that the farmer's report is a reliable indicator of the health status in his dairy herd. Furthermore, in this study we had recordings from farmers, veterinarians and technicians. However, Viring et al. (1993) found a prevalence of enteritis of 7.2\% in Swedish calves between 36 $\mathrm{h}$ and 14 days old; based on diagnoses by veterinary practitioners, which indicates a higher incidence of enteritis than the $3.5 \%$ between 8 and 30 days of age based on reports by farmers in the present paper. This difference may indicate that the incidence of enteritis in the present study was underestimated. Maybe the farmers paid no attention to mild symptoms of diarrhoea in young calves.

\section{Mortality, stillbirths, abortions}

The frequencies of $0.6 \%$ abortions, $3.6 \%$ stillborn calves and $2.6 \%$ mortality were consis- 
Table 4. Results from univariate logistic regression analysis of within-herd incidence rates of mortality between 1-7 days after birth, enteritis and morbidity between 1-7 and 8-30 days after birth.

\begin{tabular}{|c|c|c|c|c|c|}
\hline \multirow[t]{2}{*}{$\begin{array}{l}\text { Explanatory } \\
\text { variable }\end{array}$} & \multirow{2}{*}{$\begin{array}{c}\begin{array}{c}\text { Mortality } \\
(\mathrm{OR})^{\mathrm{a}}\end{array} \\
1-7 \\
\text { days }\end{array}$} & \multicolumn{2}{|c|}{$\begin{array}{c}\text { Enteritis } \\
(\mathrm{OR})^{\mathrm{a}}\end{array}$} & \multicolumn{2}{|c|}{$\begin{array}{l}\text { Morbidity } \\
(\mathrm{OR})^{\mathrm{a}}\end{array}$} \\
\hline & & $\begin{array}{c}1-7 \\
\text { days }\end{array}$ & $\begin{array}{l}8-30 \\
\text { days }\end{array}$ & $\begin{array}{c}1-7 \\
\text { days }\end{array}$ & $\begin{array}{l}8-30 \\
\text { days }\end{array}$ \\
\hline Yield level & & $1.0^{\mathrm{b}}$ & & & \\
\hline Herd size & 1.02 & 1.02 & 1.01 & & \\
\hline Zero-grazing & 3.04 & & & & \\
\hline Joint pasturage & & 3.77 & & & 2.04 \\
\hline Cows tethered at calving & 0.40 & 0.30 & & & \\
\hline Calf allowed to suckle & & 2.72 & 1.89 & 2.02 & 1.59 \\
\hline Individual pen & & 0.24 & & 0.19 & \\
\hline Slatted floor in calf pen & 2.66 & & & & \\
\hline $\begin{array}{l}\text { Contagious enteritis, } \\
\text { previously }\end{array}$ & & 2.26 & 2.12 & & 2.29 \\
\hline
\end{tabular}

a Odds ratio.

${ }^{\mathrm{b}} \mathrm{OR}=1.82$ per $1,000 \mathrm{kgs}$ of yield.

tently low. According to Roy (1990), calf mortality rates on well managed farms in western Europe during different periods were as follows: abortions, $2-2.5 \%$, stillborn calves and deaths during the first $24 \mathrm{~h}, 3.5-5.0 \%$, deaths during the periods $1-28$ days and $29-84$ days, $3 \%$ and $1 \%$, respectively.

Simensen (1982) reported from Norway that the mortality up to 30 days of age is $3.95 \%$, including stillborn calves. This figure is slightly lower than the result, $5.1 \%$, in the present study, but may be explained by the fact that the herd size is smaller in Norway. Simensen (1982) and Roy (1990) referred to a number of studies, all of which indicated that calf mortality increased with herd size. A similar connection was established in the present study. It should be pointed out that dairy herds in Sweden, with an average number of 26 cows per herd (SHS, 1987/88), are generally smaller than in many other countries in western Europe.

The frequency of $3.6 \%$ stillborn calves is about the same as the $2.93-3.86 \%$ reported for Swedish calves by Lindhé (1967). It should be noted however that the rate of stillborn calves was reported to be $4.3 \%$ in 1990 , according to milk-recording statistics in Sweden. The frequency of $0.6 \%$ abortions is higher than statistics from the Swedish artificial insemination programme with a rate of $0.2 \%$ in 1988 (SHS 1987/88), but about the same level $(0.3-0.7 \%)$ as reported by Olsson \& Elvander for the 3-year period 1986-1988.

\section{Morbidity}

The present frequencies of $7.2 \%$ enteritis, $0.8 \%$ pneumonia and $11 \%$ overall morbidity during the period 0-90 days of age are low compared with those reported by other authors, e.g. Blom (1982), who reported $10.3 \%$ enteritis and $44.0 \%$ respiratory disease in 4 Danish dairy herds comprising 193 calves. The incidence of enteritis was most common during the first 2-4 weeks, a period which also showed the highest morbidity. Curtis et al. 
(1988) investigated 1,171 heifer calves in 26 herds in the state of New York. Up to 90 days of age, $15.1 \%$ of the animals had contracted enteritis and $7.4 \%$ some form of respiratory tract disease. The difference in herd size with the consequent massing of animals may partly explain the differences between Sweden and the USA.

A connection between yield level and health in calves and young animals has been documented in only a few studies. Jenny et al. (1981) found that the calf mortality decreased in inverse proportion to increasing butterfat yield. This study indicated an increasing risk of enteritis in calves 1-7 days of age. Neither mortality nor morbidity was affected by yield level. One explanation for the increased risk of enteritis in 1-7-day-old calves may be inferior routines for the change of feeding from colostrum to milk or milk substitutes.

Other factors that impaired calf health and mortality were whether the calf had been allowed to suckle immediately after birth, whether the herd had been in contact with other animals on common pasturage, and whether there had been any previous cases of enteritis in the herd. It is not certain that a sucking calf will consume sufficient amounts of colostrum as mentioned by Jenny et al. (1981). The negative influence of contact with other animals and previous cases of enteritis may reflect a higher infection pressure in such herds. An increased risk of disease and mortality relative to different types of contacts with other herds have been demonstrated also in earlier investigations. Roy (1990) referred to studies which clearly showed a reduced mortality when the procurement of additional calves in a herd ceases.

Keeping calves in single pens is generally considered to be beneficial to calf health compared with group-penning. The present study showed a reduced incidence of enteritis.
There are, however, publications reporting contradictory results, as quoted by Simensen (1982).

It should be noted that results on herd-related variables were from univariate analyses only. Other factors could have been the true causal factors rather than the 1 observed.

It is interesting that the variation between herds was great. In the 90th percentile there were herds with $\geq 2.4 \%$ abortions, $\geq 9.0 \%$ stillborn calves, $\geq 5.8 \%$ mortality during the first month of life, $\geq 14.7 \%$ enteritis during the same age period and $\geq 20.8 \%$ overall morbidity. Consequently, there was a considerable variation between herds. It is very likely that good calf health is dependent on good management, as stated by Norman (1969) and Bakheit \& Greene (1981). Norman found indications of increased mortality in draughty and poorly ventilated calfsheds while Bakheit \& Greene emphasized the importance of hygiene and early feeding of colostrum.

Of the overall calf mortality and morbidity during the first 3-month period of life, $65 \%$ and $70 \%$, respectively, occurred during the period 0-30 days of life. Mortality and morbidity among heifers older than 90 days were both low but still accounted for $30 \%$ of the overall morbidity and mortality.

\section{Acknowledgements}

The cooperation of practising veterinarians and animal health veterinarians in the trial areas is greatly appreciated. This work was made possible by funding from the Farmers' Research Council for Information and Development.

\section{References}

Anonymous: Swedish Association for Livestock Breeding and Production 1987/88 and 1989/90. Annual statistics. Publ. No. 159 and 167, respectively. (In Swedish.) Svensk Husdjursskötsel. Årsstatistik 1987/88 och 1989/90. Meddelande nr 159 resp. 167. 
Bakheit HA, Greene HJ: Control of bovine neonatal diarrhoea by management techniques. Vet. Rec. 1981, 108, 455-458.

Blom JY: The relationship between serum immunoglobulin values and incidence of respiratory disease and enteritis in calves. Nord. Vet. Med. 1982, 34, 276-284.

Curtis CR, Erb HN, White ME: Descriptive epidemiology of calfhood morbidity and mortality in New York Holstein herds. Prev. Vet. Med. 1988, 5, 293-307.

Ekesbo I: Disease incidence in tied and loose housed dairy cattle. Ph.D. Thesis. Acta agric. scand. 1966, Suppl. 15, 22-23.

Hartman DA, Everett RW, Slack ST, Warner RG: Calf mortality. J. Dairy Sci. 1974, 57, 576-578.

Jenny BF, Gramling GE, Glaze, TM: Management factors associated with calf mortality in South Carolina dairy herds. J. Dairy Sci. 1981, 64, 22842289.

Lee ET: Statistical methods for survival data analysis. Lifetime Learning Publications 1980, Belmont, Calif., USA, 557 pp.

Leeck FB, Macrase WD, Menzies, DW: Calf wastage and husbandry in Britain 1962-63. Animal disease surveys. Report No. 5, 1968, Ministry of Agriculture, Fisheries and Food, London 1968, $59 \mathrm{pp}$.

Lindhé B: Studier över frekvensen dödfödda och misskildade kalver inom svenska nötkreaturerne. Svensk Husdjurskötsel. Meddelande nr 13. 1967. (Studies on the rate of stillbirths and congenital abnormalities in Swedish cattle breeds). Swedish Association for Livestock Breeding and Production. Publ. No. 13, 1967).

Norman JA: The housing of young cattle. Vet. Rec. $1969,85,429-432$.

Olsson S-O, Elvander M: Abortions in Swedish dairy cattle 1986-1988. Unpublished data.
Roy JHB: The calf; Management of health, Butterworths, London, 1990.

SAS Institute Inc.: SUGI Supplemental Library User's Guide, 1983 edition. SAS Institute Inc., Cary, NC, USA, 402 pp.

SAS Institute Inc.: SAS User's Guide: Statistics, 1985 version, 3rd Edition. SAS Institute Inc., Cary, NC, USA, 956 pp.

Simensen E: An epidemiological study of calf health and performance in Norwegian dairy herds. Acta agric. scand. 1982, 32, 411-419.

Viring $S$, Olsson SO, Alenius S, Emanuelson U, Jacobsson SO, Larsson B, Linde N, Uggla A: Studies of enteric pathogens and immunoglobulin levels of neonatal calves in Sweden. Acta.vet. scand. 1993, 34, 261-269.

\section{Sammanfattning \\ Sjuukdomar och dödlighet hos kalvar i svenska be- rättningar med mjölkkor.}

Undersökningen redovisar kalvhälsoläget i 131 besättningar med mjölkkor med tillsammans 5.050 kalvningar. I jämförelse med andra västeuropeiska länder är mortaliteten och morbiditeten låg. Frekvensen aborter och dödfödda kalvar är 0,6 respektive $3,6 \%$. Mortalitet och morbiditet redovisas för 4.839 levande födda kalvar. Under perioden 0-90 dagars ålder är frekvenserna för mortalitet, enterit, pneumoni och morbiditet 2,6, 7,2, 0,8 respektive $11,0 \%$. Faktorer som ökar dödlighet och sjukdomsförekomst på individnivå är bl. a. moderns ålder, moderns ras, kalvningssäsong och kalvens ålder vid första råmjölksgiva. Bland besättningsfaktorer som påverkar kalvhälsan negativt kan nämnas besättningsstorlek, året runt på stall, gemensamhetsbeten och om kalven får dia modern.

(Received March 5, 1993; accepted March 10, 1993).

Reprints may be requested from: S.-O. Olsson, Swedish Association for Livestock Breeding and Production, Animal Health Department, S-631 84 Eskilstuna, Sweden. 